Amrullah Ramdani, Dlis Firmansyah, Hernawan. Model of sickle kick pencak silat training based on exercise media in students pencak silat athletes. Journal of Education, Health and Sport. 2020;10(4):11-19. eISSN 2391-8306. DOI http://dx.doi.org/10.12775/JEHS.2020.10.04.001

https://apcz.umk.pl/czasopisma/index.php/JEHS/article/view/JEHS.2020.10.04.001

https://zenodo.org/record/3737259

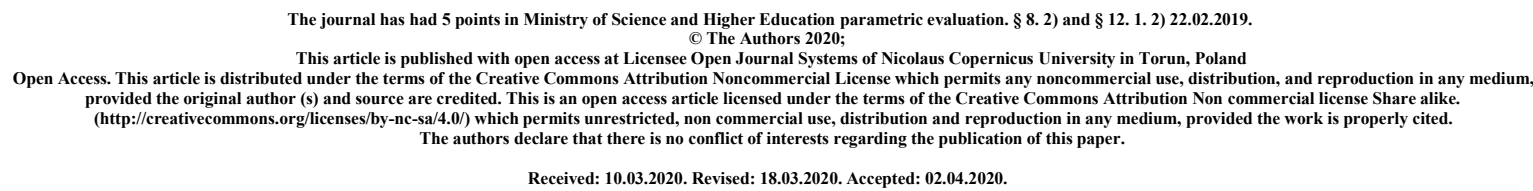

\title{
MODEL OF SICKLE KICK PENCAK SILAT TRAINING BASED ON EXERCISE MEDIA IN STUDENTS PENCAK SILAT ATHLETES
}

\author{
(Research and Development Study Model of Sickle-Based Exercise Kick Media \\ Training of Student Athletes)
}

\author{
Ramdani Amrullah ${ }^{1}$, Firmansyah Dlis ${ }^{2}$, Hernawan ${ }^{3}$
}

${ }^{1}$ Sports Education Study Program, Post-graduate Universitas Negeri Jakarta, St. Rawamangun Muka, East Jakarta 13220, Indonesia ramdaniamrullah_7217167415@mhs.unj.ac.id

${ }^{2}$ Sports Education Study Program, Post-graduate Universitas Negeri Jakarta, St. Rawamangun Muka, East Jakarta 13220, Indonesia firmansyahdlis@unj.ac.id

${ }^{3}$ Sports Education Study Program, Post-graduate Universitas Negeri Jakarta, St. Rawamangun Muka, East Jakarta 13220, Indonesia hernawan@unj.ac.id

\begin{abstract}
Introduction. Techniques kick is most often used in competition and in the game selfdefense more than $90 \%$ points scored by the kick competition that kicks effectiveness depending on various factors, such as the maximum strength of the muscles involved in the level of development of strength, coordination neoromuscular, the linear velocity and the angle of the ankle when kicking leg and improve coordination between agonists and antagonists. develop a model exercise kick sickle-based media practice, because the model through the medium of exercise is a model of long-term and continuous change constantly, because this type of training will develop with regard to the development of athletes in accordance with the specifications of the branch sport, and System and method of exercise is getting day also thanks to the support of increasingly sophisticated equipment, facilities and
\end{abstract}


infrastructure that is more modern.

Objective of the study. This study aims to determine whether the basic Technical skills learning model based media workout sickle kick effectively improve the skills and abilities of the sickle kick pencak silat sport student athletes.

Research methods. Studies that use mixed methods research approach that combines qualitative and quantitative methods. Research Quantitative used to find the effectiveness of the True-Experimental research design shaped the pretest-posttest control group design.

Research result. Initial tests ability sickle kick right and left of 6.944, 6.39. 65.22 skill being right, and left 71.26. after being given treatment ability right sickle kick 8.70 and 8.04 left. Skills right $62.48,68.66$ to the left.

Conclusion. Based on the results of data from field trials and discussions can be concluded that this type of training with exercise effective media to enhance the capabilities and skills of the sickle kick sports pencak silat students.

Key words: Model, Sickle kick, Swiss ball

\section{Introduction}

Pencak silat is a sport that is competitive, which aims to achieve maximum performance for those working in the field or branch either individually or in teams. His achievement by (Harsono, 2017: 39) there are four aspects that must be considered and carefully trained by athletes that physical exercise, exercise techniques, tactics and mentally exercise, and ought to four aspects was to be effective and can accounted for through a scientific approach. Kick is one of the techniques of motion in the sport of pencak silat that have a high value and by(Moreira et al., 2016), The kick is the technique most often used in the competition, according (Kazemi et al., 2010) In the pencak silatgame for more than $90 \%$ points scored by the kick competition while according to (Gavagan \& Sayers, 2017) Roundhouse kick is also the most frequently used in the competition. Pencak Silat in Indonesia, there are two basic terms, namely pencak silat. According to (Lubis, Johansyah, 2014: 2), Pencak silat term usually used by people who inhabit the island of Java, especially in West Java, while silat is often used by people who are on the island of Sumatra or also commonly used term wrangle. according to the great dictionary Indonesian pencak silat is defined game (skills) in self-defense to fend intelligence, attack, and defend themselves with or without weapons. According to (Kartomi, 2011), Pencak silat refers to two components, pencak silat is a performing arts while fighting and martial arts.

Sickle kick by (Notosoejitno, 1997: 66), Is a kick executed by using the hand of the feet and legs, the trajectory of the side and the subject on the back foot. Meanwhile, according Johansyah, " sickle kick, kick down the tracks in a semicircle, with the goal of the entire body with the back foot or finger foot"(Lubis, Johansyah, 2014: 39), sickle kick, referring to the name implies, is a technique that is cross-kick movements form a semicircle or a kick line's how it works similar to a sickle (arit/clurit), which swung from the outer side toward the side. 
Kick which has a good ability to be supported by the ability of muscles that good anyway. Leg and abdominal muscles that are used in the kicking had the muscles of the ankle joint, leg with his duties according (Rasch, 1978: 330), As follows: the extrinsic muscles consist of terbialis anterior, extensor digitorum longus, peroneus tertius, extensor longus hallucius, gastroenemius, plantaris, soleus, peroneus longus, peroneus brevis, flexor digitorum longus, flexor halluces longus and tibialis posterior. while according to (Frederic Delavier, 2013: 94), Stating that the work contracted muscles when a kick is different from the far understandable, it turns out the attack power kick, the actual strength of the kick comes from the psoas and Iliacus, while the rectus femoris is the only one thigh muscles that support the hip flexors, while for sabilisasi makes fall while standing only one leg, is provided by the gluteus medius and calves, so here's four muscle groups that need to be strengthened. While (Valdes-Badilla et al., 2018) states to improve the efficiency of work or in training trainers kick for kick roundhouse kick to train part of the soleus muscle group, rectus femris, biceps femoris, vastus medialis, semitendinoid and hamstring muscles when exercising kick. Based on some opinions on how good a coach in training sickle kick kicks particular train specific muscles needed to kick the sickle itself based on the research and opinions of experts in their field, Joints were working at the time to kick in (Mcninnis, Peter, 2005: 318), Is the ankle, knee, hip, shoulder, and elbow on both sides of the body. While working muscles are the muscles of the abdomen, upper leg, lower leg and foot muscles. While working on the joints when doing kick by (Mcninnis, Peter, 2005: 318), Is the ankle, knee, hip, shoulder, and elbow on both sides of the body. While working muscles are the muscles of the abdomen, upper leg, lower leg and foot muscles.

Learning movement (motor learning) is a relatively permanent change in performance or behavioral changes resulting motion of thanks to the training or experience in the past (David L. Galahue, 2009). As (Richard A. Schmidt, 2000) provides a clearer picture about the study of motion or commonly called the motor learning with learning declare the motion is a series of processes that are associated with training or experience that lead to changes in a relatively permanent change in one's ability to show movement skilled movements. Presented (Coker, 2004) which states that: "Motor learning is the study of the processes Involved in acquiring and refining of motor skill and of variables that promote or inhibit that acquisition" Learning motor is the study of the processes involved in obtaining and enhance motor skills and the variables that drive or inhibit the acquisition of such, while according to (Widiastuti, 2015) in his book states learn movement is a movement that follows the pattern or shape that gain coordination and partial control or the entire body can be done through the learning process, so someone who is able to do the movements well and is said to be skilled is the person who is able to perform motion tasks efficiently and effectively.

The process of movement in the achievement of learning objectives motion always through the stages or phases of learning that can be identified through the three phases of learning, namely (1). Cognitive phase or initial phase,Cognitive stage is the beginning of the stages of learning according to the model Fitt and Potsner, where this phase students trying to grasp the idea or concept of movement by listening to an explanation or see examples of the movement, appearance motor during this stage is characterized by a large number of errors, the appearance of a very varied which shows lack of consistency of some other experiments, and although students may realize that they are doing something wrong, they generally do not know what to do to improve his performance (Coker, 2004), based on the explanation that the cognitive stage is very important and needs attention more for children or students in the next move already branching not experiencing errors (2). Associative phase or an intermediate phase is also called the stage of completion, where after students practicing repetitive motion, 
motion learning process will enter a phase where in performing motor skills, movement concept you have in mind is getting easier to implement in response to movement.

This stage is characterized by students become increasingly able to not only detect the cause of the error, but also to develop appropriate strategies to eliminate these errors. Giving information about the error remains crucial for improving skills and for further development in detecting and correcting errors student (Coker, 2004), The conclusion of this stage is the stage of refinement associative movement pattern of cognitive stages are characterized by movement more effective and efficient where the fault movement on the wane, (3). Phase autonomous or final phase of the model phase of motion, and is the crowning achievement of the skills movement, here students have been able to make a move autonomously or automatic and autonomous movement and automatically be formed through a process of training or practice repeatedly in a period of relative long (Nonis P. Karen and Jernice Sing Yee Tan, 2014), This stage is marked by the appearance of the movement of students to be consistent, confident, make a little mistake and ability of motion are the main things that must be considered because everyone has the ability to move different, these differences would affect the easy or not in the execution of motion and can usually detect and correct an error (Coker, 2004),

Exercise by (Bompa Tudor O and Michael Carrera, 2009: 2) exercise is the process in which one athlete is prepared for the highest performance. Meanwhile, according Harsono in (Tangkudung, 2012: 42) Exercise is a set of activities in practice are arranged so that can be implemented by the students student/athletes, both on the amount of training load and intensity of the exercise. According to Bowers and foss fox in (Budiwanto, 2012: 16), Exercise is a physical exercise program to develop an athlete's ability in the face of an important game.

Exercise by Apta (2015: 47) is derived from the English language that can contain multiple meanings such as; practice, exsercises, and training. Definition of exercise comes from the practice according to (Sukadiyanto Dangsina, 2011: 6), Is an activity to improve the skills (skills) exercise using a variety of equipment in accordance with the objectives and needs of the sport. Definition of exercise derived from the word exercise is the main device in the process of daily practice to improve the quality of human organ system function, making it easier for an athlete in motion refinement.

Every form of exercise performed by sportsmen have a special purpose. Therefore any form of stimulus will be processed specifically also by the athlete, so the training material should be selected keeping with the needs of branches of sport. To that end, as a consideration in applying the principles of the specification, among others determined by: (a) the specification of its energy needs, (b) specification of the form and method of practice, (c) specification of the characteristics of motion and muscle groups that are used, and (d) the time of periodization training, the application of the principle of specialization should be adjusted to the age of the athlete to avoid things that are not desirable. The principle of specification according to (Tangkudung, 2012: 59),

In particular students aged 12-18 years entered the first middle school and high school. According to (Bompa, 2000: 4)12 years of age is the right age to start the fight training and specialization stage at the age of 15-16 years. According to. (Lumintuarso, 2013: 153) At the time the child goes to $12-18$ years in the early phase of puberty so that physical exercise is recommended to use their own body weight because children do not have the muscles and bones strong, because that child is still in the growth of bones that causes most of them vulnerable to impact and load heavy. Meanwhile, according to (Bompa, 2000: 96) there are three (3) rules that need to be considered in adolescent athletes train, 1). Develop flexibility, 
2). Developing tendon before muscle strength, 3). Developing core muscle strength (core) before other forces. In every stage of life of the child, the child has a developmental specific characteristics in each stage. Although each of these stages has characteristics that are typical, but the stages are not independent, but interrelated.

Understanding media by (Arsyad, 2013), Said that the word comes from the word medius media which literally means middle, intermediary, or introduction, which means an intermediary or an introductory message from the sender to the receiver. Meanwhile, according Suranto (2005: 18) states that the media is a means by which to convey a message from someone communicator to the communicant. (Trini, Prastati ,. Prasetya, 2005: 3) give meaning as any media that can distribute information on resources to the recipient of the information. More specifically Briggs in (Trini, Prastati ,. Prasetya, 2005: 4) says the media as the physical means to convey the content or learning materials .. The (Djamarah, 2002: 136) defines media as a tool for just about anything can be used as a vehicle for channeling information learned or channeling messages in order to achieve the learning objectives, while Sri anitah (2012), defines the learning media is every man, material, equipment or events that can create conditions that allow learning to received the knowledge, skills, and attitudes

Stability ball exercises fleksibilityatu also called Swiss exercise ball is a rubber ball measured between $45 \mathrm{~cm}$ to $120 \mathrm{~cm}$ and this ball supple and springy nature and use customized posture. According to (Beate, 1998: 1), Swiss ball first introduced in London in 1967 for physical therapy and is used for movement memfalisilitasi children. Furthermore swiss ball is used for physical therapy, one of which stabilizes the unstable muscle becomes unstable because the ball is made of rubber will increase the muscles that have not done function becomes activated back. (Lehman et al., 2006) The findings suggest that an unstable surface that is assumed to produce a destabilizing effect and increased muscle activity. This exercise is very easy, safe and attractive to use and can be used by all age levels, both men and women. This exercise without requiring a large space and a special room.

Swiss ball by (Beate, 1998: 3), Also used for health care for neurological and orthopedic patients and especially the treatment requires a bone stability. According to Rutherford and Jones in Stanton, Peter, Raeburd and Humpies (2004: 522-528) suggests that adaptations of Swiss exercise ball tends to produce a synergistic muscle coordination and better stabilization, consistent statement of Check-in (Tanton, Eaburn, and Umphries, 2004: 522-528) stated that the Swiss ball training increases neuromuscular pathways which leads to a strength and a greater balance. In line with (Song et al., 2015) that the swiss ball can improve muscle strength, endurance, flexibility, and coordination and are used to improve the ability to balance the perceptual, besides (Song, Kim, \& Park, 2015: 3879-3882), Stated. Swiss ball exercises to effectively improve the balance, in line with the (Sekendiz et al., 2010), (Michael, F and Tammara, 2005), (Brukner, P and Khan, 2006) Swiss Ball exercises are emphasized as an effective training tool to improve core strength, improve spinal stability and flexibility in physiotherapy. Therefore the swiss ball exercises that use stability on the ball, then the ball during practice with the necessary balance and coordination can be trained simultaneously with the power and stability. In line with the results of the study (Paul WM Marsall, 2010), Provide evidence supporting the hypothesis that the swiss ball exercises can obtain commensurate muscle activity and recommended for strength training and exercise is also good to use when the body in an unstable state so that the swiss ball can activate the muscles according to function, and according to research results (Tanton et al., 2004: 522528), It seems that Swiss ball training can positively affect the stability of the core without simultaneously increase physical performance in athletes. This exercise also without loading exercise but use the upper limbs and lower limbs at the same time. 
Some previous studies that have been made and are considered relevant enough or is linked to titles and topics to be studied are useful to avoid the repetition of studies with the same subject matter and serve as one form of enriching reference source before the results of research studies,

(Wasik \& Shan, 2015) Research by title Target effect on the kinematics of Taekwondo Roundhouse Kick is the presence of a physical target of a stimulus, Influencing musclepower generation, results of this study showed only that training with and without physical targets will develop a pattern of motor control that is different and more research is needed to eliminating knowledge of roundhouse kicks are effective and efficient training.

(Sudirman, 2015)The study entitled Effect of plyometrics training methods and maxex with force against the speed of the sickle kick pencak silat in STKIP faithful budhi Rangkasbitung, this study used an experimental method with factorial design $2 \times 2$. Sampling using cluster random sampling technique. The study concluded that for the group of students who have the core strength of the muscle-yield speed drills kick sickle better when trained with training methods maxex, with while the group that has core strengths low muscle tone, the result of speed drills kick sickle better when trained with training methods plyometrics.

(Maulana \& Wijaya, 2018)The study entitled Effect of Exercise rubber tires and ballast legs to speed sickle kick pencak silat fighter extracurricular daughter SMP Negri 2 Mount Thunder Sukabumi 2017/2018. This study This study used media ballast rubber tires and feet in the implementation of the training process. From the analysis of data showed that the sickle kick velocity using the medium tire rubber exercise has a better percentage increase in speed compared to using leg weights $0,5 \mathrm{~kg}$ media. this is because the properties of elasticity and resilience owned rubber inner tube.

(Solissa, Tangkudung, 2015) Researchers entitled The Effect of Training Methods and the motor ability to power dollyo chagi Taekwondo kick. In the study there were findings that prove that the motor skills necessary to be considered in developing the power kicks Taekwondo, training to improve with the first kick. improve motor skills. This study proved that training methods plyometrik more effective to increase the strength of dollyo chagi Taekwondo kicks.

(Amrullah, 2015) This study aims to determine the effect of resistance training exercises Xander (TRX) on the ability of the sickle kick pencak silat sport, The method used in this research is the method of experiment with the design of a complete block design One group pretest-posttest-designIn conclusion there is significant influence from TRX Training Methods Against ability sickle kick, proved that the value of $\mathrm{t} 25.44>\mathrm{t}$ table 2.13.

After going through the stages of research and development of a long and a few trials, based on a needs analysis test experts, the small group trial and testing of large groups come to test the effectiveness of the product, it can be concluded that this type of training kick sickle-based media workout unfit for use, as well as highly effective as an increased knowledge and understanding of this type of training athletes in sickle kick. Overall product development researchers generated based on the stages of research development feasible and meets the criteria can be applied in practice kicks, especially the sickle kick.

\section{Objective of the study}

Based on the previous analysis, the objectives are to determine whether the modelbased media sickle kick practice this exercise effective for athletes pencak silat students.

\section{Research methods}

The study, the authors propose a study that used a mixed methods research approach that combines qualitative and quantitative methods. quantitative approach is used to find the effectiveness of the True-Experimental research design shaped the pretest-posttest control 
group design. Subjects in research and development are student athletes in London and Tests performed in London with a large number of 5 college with respondents as many as 100 people were divided into two groups, one experimental group with the number of respondents 50 and one control group of 50 respondents, the results of product trials conducted over 12 meetings. Qualitative descriptive analysis techniques in the form of interpretation of the data from the questionnaire the subject of research, interpretation of scores calculated by the score acquisition of each item. In addition to qualitative data, data analysis techniques used in this study is also in the form of quantitative data. Quantitative data is data obtained using instruments such as the attitude scale (Likert scale) and the results of pre-test and post-test and compared between the two

\section{Result}

Based on the output results by using SPSS 16 that the average value of the result of the ability of kick sickle right before the given model of 6.9440 and after being given the treatment with the model 8.7034 means that the average value of the ability of kick sickle right there is an increase in tests of significance difference with SPSS 16 may be the result of $\mathrm{t}$-count $=20: 59$, df $=49$ and $\mathrm{p}$-value $=0.00<0.05$ which means there is a significant difference in the ability of the sickle kick right before and after the treatment model of mediabased exercise workout kick.

Based on the output results by using SPSS 16 that the average value of the result of the ability left before the sickle kick awarded after the model of 6.3900 and 8.0404 given treatment model means that the average value Sickle Kick Left ability there is an increase. While the difference in the significance test with SPSS 16 may be the result of t-test $=18: 44$ $\mathrm{df}=49$ and $\mathrm{p}$-value $=0.00<0.05$ which means there is a significant difference in the ability of the sickle kick left before and after the treatment model of media-based exercise workout sickle kick.

The average yield pretest skills right sickle kick is 65.22 , after treatment with a sickle kick exercise workout model of media-based exercises. Sickle kick right skills further after the treatment is carried out post-test or the final test and the average value of post-test was 71.26. In a test of significance of the difference with SPSS 16 may be the result of t-test $=$ 32.00 , df $=49$ and $\mathrm{p}$-value $=0.00<0.05$ which means there are significant differences left sickle kick skills before and after the treatment model of an exercise using exercise media

Based on the output results by using SPSS 16 that the average value of the results of the sickle kick right skills before being given a model of 65.22 and after 71.26 given treatment model means that the average value of the sickle kick skills right there is an increase. In a test of significance of the difference with SPSS 16 may be the result of t-test $=$ $25.64, \mathrm{df}=49$ and $\mathrm{p}$-value $=0.00<0.05$ which means there are significant differences sickle kick right skills before and after the treatment model of media-based exercise workout sickle kick.

Based on the output results by using SPSS 16 that the average value of the results of Sickle Kick Skills Left before the given model of 62.48 and after 68.66 given treatment model means that the average value of the sickle kick skills left there is an increase. In a test of significance of the difference with SPSS 16 may be the result of t-test $=32.00, \mathrm{df}=49$ and $\mathrm{p}$-value $=0.00<0.05$ which means there are significant differences left sickle kick skills before and after the treatment model of an exercise using exercise media.

\section{Discussion}

Overall product development phases of research generated by the development of feasible and meets the criteria can be applied in practice kicks, especially the sickle kick. Nevertheless researchers found several weaknesses and shortcomings of the products are 
made, but to get the product better training models, while some records were obtained based on the findings in the field:

a. Product model of media-based exercise workout sickle kick just examine variations in outline and needs to assess variations in more detail by experts skilled in the art with sport saince approach.

b. Model-based media sickle kick this practice should be continued with the development research with the overall ability in accordance with the anatomical and movement analysis needs of athletes

c. Implementation of the model-based media sickle kick workout exercises can not be controlled, because the understanding of the need for sport saince coach in training.

\section{Conclusion}

Based on the results of data from field trials and discussions can be concluded that this type of training with exercise effective media to enhance the capabilities and skills of the sickle kick pencak silatsport teen

\section{References}

Amrullah, R. (2015). Pengaruh Latihan Training Resistense Xander Terhadap Kemampuan Tendangan Sabit Pencak Silat Ramdani Amrullah. Jurnal Pendidikan Olahraga, 4(1), $88-100$.

Arsyad, A. (2013). Media Pembelajaran. Raja Grafindo Persada.

Beate, C. (1998). The Swiss Ball, Theory, Basic Exercise and Clinical Applicate. SpringerVerlag Berlin Heidelberg.

Bompa, T. o. (2000). Total For Young Champion. Versa Press.

Bompa Tudor O and Michael Carrera. (2009). Priodization theory And Methologi Of Training. USA : Human Kinetik. Human Kinetic.

Brukner, P and Khan, K. (2006). Brukner, P and Khan, K. Core stability. In: Clinical Sports Medicine (3rd ed.). Sydney: McGraw Hill, 2006. pp. 158-159. Clinical Sports Medicine, $158-159$.

Budiwanto, S. (2012). Metodologi Latihan Olahraga. UMN.

Coker A, C. (2004). Motor Learning and Control for Practitioners. McGraw-Hill.

Djamarah, S. B. dan A. Z. (2002). Strategi Belajar Mengajar, Cetakan Kedua. Rineka Cipta.

Frederic Delavier, M. G. (2013). Mixed Martial arts Anatomy. Human kinetic.

Gavagan, C. J., \& Sayers, M. G. L. (2017). A biomechanical analysis of the roundhouse kicking technique of expert practitioners: A comparison between the Martial arts disciplines of Muay Thai, Karate, and Taekwondo. PLoS ONE, 12(8), 1-15. https://doi.org/10.1371/journal.pone.0182645

Harsono. (2017). Kepelatihan Olahraga teori dan metodologi. Remaja Rosdakarya.

Kartomi, M. (2011). Traditional and Modern Forms of Pencak Silat in Indonesia: The Suku Mamak in Riau Traditional and Modern Forms of Pencak Silat in Indonesia: The Suku Mamak in Riau. 5857. https://doi.org/10.1080/08145857.2011.580716

Kazemi, M., Perri, G., \& Soave, D. (2010). A profile of 2008 Olympic Taekwondo competitors. The Journal of the Canadian Chiropractic Association, 54(4), 243-249. http://www.ncbi.nlm.nih.gov/pubmed/21120015\%0Ahttp://www.pubmedcentral.nih.gov /articlerender.fcgi?artid=PMC2989396

Lehman, G. J., MacMillan, B., MacIntyre, I., Chivers, M., \& Fluter, M. (2006). Shoulder muscle EMG activity during push up variations on and off a Swiss ball. Dynamic Medicine, 5, 1-7. https://doi.org/10.1186/1476-5918-5-7

Lubis, Johansyah, H. W. (2014). Lubis, Johansyah, Hendro Wardoyo (2014). Pencak Silat, Jakarta: PT. Raja Grafindo Persada. Raja Grafindo Persada. 
Lumintuarso, R. (2013). Pembinaan Multilateral Bagi Atlet Pemula. UNY Press.

Maulana, A., \& Wijaya, M. R. A. (2018). Terhadap Kecepatan Tendangan Sabit Pesilat Putri Ekstrakurikuler Pencak Silat Smp Negeri 2 Gunung Guruh Kabupaten Sukabumi 2017 / 2018. Jurnal Repository Ummi, 142-147.

Mcninnis. Peter. (2005). Biomechanics, Of Sport and exercise. Human kinetic.

Michael, F and Tammara, M. (2005). Muscular balance, core stability, and injury prevention for middle- and long-distance runners. Phys Med Rehab, 16, 669-689.

Moreira, P. V. S., Goethel, M. F., \& Gonçalves, M. (2016). Neuromuscular performance of Bandal Chagui: Comparison of subelite and elite taekwondo athletes. Journal of Electromyography and Kinesiology, 30, 55-65. https://doi.org/10.1016/j.jelekin.2016.06.001

Nonis P. Karen and Jernice Yee Sing Tan. (2014). The gross motor skills of children with mild learning disabilities. International Journal Of Special Education, 29(2).

Notosoejitno. (1997). Khadazah Pencak Silat. Sugeng Seto.

Paul W.M. Marsall, I. D. (2010). Electromyographic analysis of upper body, lower body, and abdominal muscles during advanced Swiss ball exercises. Journal Strength and Conditioning Research, 24(6), 1537-1545.

Rasch, P. J. dan R. K. B. (1978). Kinesiologi and Applied Anatomy. Lea \& Febiger.

Sekendiz, B., Cuğ, M., \& Korkuz, F. (2010). Effects of Swiss-ball core strength training on strength, endurance, flexibility, and balance in sedentary women. Journal of Strength and Conditioning Research, 24(11), 3032-3040. https://doi.org/10.1519/JSC.0b013e3181d82e70

Solissa, J., Tangkudung, J. A. P., Program, R. S., \& Jakarta, U. N. (2015). The effect of training method and motor ability. 1(1), 50-56.

Song, G. Bin, Kim, J. J., \& Park, E. C. (2015). The effect of Swiss ball exercise and resistance exercise on balancing ability of scoliosis patients. Journal of Physical Therapy Science, 27(12), 3879-3882. https://doi.org/10.1589/jpts.27.3879

Sudirman, R. (2015). Pengaruh Metode Latihan Pliometrik Dan Maxex Dengan Kekuatan Terhadap Kecepatan Tendangan Sabit Pencak Silat Di Stkip Setia Budhi Rangkasbitung. Jurnal Multilateral, 14(1), 54-61.

Sukadiyanto Dangsina. (2011). Pengantar Teori dan Metodologi Melatih Fisik. Lubuk Agung.

Tangkudung, J. (2012). Kepelatihan Olahraga Pembinaan prestasi Olahraga (edisi 2). Cerdas Jaya.

Tanton, R. O. S., Eaburn, P. E. R. R., \& Umphries, B. R. H. (2004). On core stability and running economy. 18(3), 522-528.

Trini, Prastati, Prasetya, . Irwan. (2005). Trini, Prastati,. Prasetya,. Irwan. (2005). Media Sederhana. Jakarta: PAU Dirjen Dikti Depdiknas. PAU Dirjen Dikti Depdiknas.

Valdes-Badilla, P., Medina, M. B., Pinilla, R. A., Herrera-Valenzuela, T., Guzman-Munoz, E., Perez-Gutierrez, M., Gutierrez-Garcia, C., \& Salazar, C. M. (2018). Differences in the electromyography activity of a roundhouse kick between novice and advanced taekwondo athletes. Ido Movement for Culture, 18(1), 31-38. https://doi.org/10.14589/ido.18.1.5

Wąsik, J., \& Shan, G. (2015). Target effect on the kinematics of Taekwondo Roundhouse Kick - Is the presence of a physical target a stimulus, influencing muscle-power generation? Acta of Bioengineering and Biomechanics, 17(4), 115-120. https://doi.org/10.5277/ABB-00229-2014-02 